\title{
Potential for the use of duckweed-based pond systems in Zimbabwe
}

\author{
Innocent Nhapi \\ Department of Civil Engineering, University of Zimbabwe, Box MP167, Mt Pleasant, Harare, Zimbabwe
}

\begin{abstract}
Duckweed systems are a form of natural wastewater treatment method that is ideal for developing countries. They demand less in terms of financial resources for construction and maintenance, manpower sophistication, electricity requirements, and machinery. This paper looks at the duckweed technology as a new phenomenon in Zimbabwe, reviews its requirements and problems, and finally explores its potential in the Zimbabwean environment. A simple spreadsheet model was developed to assess a water and nutrient balance of an ideal duckweed system. It was concluded that under ideal or optimum operating conditions, duckweed systems could achieve the required Zimbabwean nutrient standards of $10 \mathrm{mg} \cdot \ell^{-1}$ total nitrogen and $1 \mathrm{mg} \cdot \ell^{-1}$ total phosphorus. Duckweed systems would suit areas of moderate to high water consumption to avoid toxicity problems and also to increase the surface area available for duckweed growth. It was recommended that further experiments be carried out locally to improve and validate the model developed and used in this paper.
\end{abstract}

Keywords: duckweed, mass balance model, nutrient recovery, pollution control, reuse options, wastewater treatment

\section{Introduction}

The management of wastewater has traditionally focused on the reduction of organic loading, nutrient removal, and pathogen elimination. The approach has been to address these through technological options, most of them high-tech. Land requirements and the need to dispose of high quantities of industrial, commercial, and domestic sewage have so far favoured this direction. However, the emergence of smaller urbanising areas of predominantly poor and middle-class populations reduces the economy of scale advantages and has often made such technologies uneconomical and unsustainable. It is debatable whether land is a genuine constraint in most developing countries, especially in small towns and growth points. Another factor that brings into question the traditional approach is whether the growth momentum of the past decades will be sustained. This is important since designs are made for a certain design period and operation and financial problems are likely to be faced if the plants continue to be under-utilised. It is in this view that modern researchers are now advocating for natural treatment methods coupled with recovery and reuse of water and nutrients in a decentralised approach to wastewater management (USEPA, 1997; Venhuizen, 1997; RMI, 2000; Lens et al., 2001). The popular natural treatment methods include waste stabilisation ponds (WSP), duckweed-based pond systems (DPSs), and constructed wetlands (CW).

The current cost of wastewater treatment in Zimbabwe is very high and almost unaffordable (Nhapi et al., 2002). In such a scenario, environmental sustainability, investment and operational efficiency are three important goals. The first goal implies that the

\footnotetext{
* To whom all correspondence should be addressed.

푱 +263 23414 529; fax: +263 4 303288; e-mail: inhapi@eng.uz.ac.zw Received 29 October 2002; accepted in revised form 1 October 2003.
}

current environmental integrity is preserved or improved for future generations and it involves meeting set environmental quality standards. Investment efficiency is a powerful argument for getting funding support, while operational efficiency helps ensure that available resources are used to expand coverage as widely as possible. These goals can be best achieved by constructing small sewage treatment plants for each development with treatment particular to the type of wastewater generated.

The recent application of duckweed technology in wastewater treatment vs. recent shift in approaches to wastewater management is quite interesting and revealing. Some researchers believe that the best solution to problems of centralised (offsite) treatment is to go for household-centred sanitation (DLG, 1998; King, 2000). Despite this, the handling of combined wastewater remains an attractive option where retrofitting is difficult for economic, social (acceptability) and other reasons. Duckweed systems are one of the options that have been widely applied for combined handling of wastewater with the nutrients used for poultry and aquacultural projects (Gijzen and Kondker, 1997; FAO, 1999; Nhapi et al., 2001). The pollutant removal efficiency of duckweed-based pond systems varies widely depending on retention time, water depth, initial nutrient concentration, duckweed density, used genera type, and harvesting regimes. Some figures are: Nitrogen 34 to $99 \%$, phosphorus 12 to $92 \%$, and BOD $_{5} 65$ to $90 \%$ (Oron et al., 1984; FAO, 1999).

This paper is based on a literature review of duckweed technology and case studies of duckweed-based pond systems in Zimbabwe. It looks at critical parameters that would determine duckweed growth and the problems that would likely arise. The actual problems that would be expected in Zimbabwe are examined through case studies with the latter part of this paper dealing with potential results if duckweed systems are optimally managed. This was achieved by developing a simple spreadsheet model based on literature values and local figures. 


\section{Duckweed use in Zimbabwe}

\section{The advent of duckweed systems in Zimbabwe}

The duckweed plant is prevalent in almost all parts of Zimbabwe and becomes noticeable where there are standing bodies of nutrient-rich waters. It also occurs in most decommissioned sewage treatment units. Pilot studies on DPS were started in 1996 by the Institute of Water and Sanitation Development (IWSD). The pilot scheme used a retention time of $20 \mathrm{~d}$, which was later changed to $35 \mathrm{~d}$ after problems with ammonium removal. The $\mathrm{pH}$ ranged from 7 to 8 , which precluded algal growth and subsequent free ammonia production (FAO, 1999). The IWSD started work on two full-scale DPS in June 1999 at Nemanwa and Gutu growth points (urbanising centres) in the Masvingo Province of Zimbabwe. These centres have respective populations of about 5000 and 10000 . Existing waste stabilisation ponds were used. Bamboo floating booms subdivided the ponds into $15 \mathrm{~m}$ by $20 \mathrm{~m}$ bays, helping in controlling wind effects. Duckweed was harvested from the subdivisions at the rate of 80 to $160 \mathrm{~kg} \cdot \mathrm{ha}^{-1} \cdot \mathrm{d}^{-1}$ (wet mass) and this was increased to $190 \mathrm{~kg} \cdot \mathrm{ha}^{-1} \cdot \mathrm{d}^{-1}$ for Nemanwa because of the low influent volume (IWSD, 1999). The duckweed was dried in sheds covered with a Hessian cloth to allow a limited amount of light to penetrate and a perforated, raised floor allowed the draining of water. Air-drying in the shade took $4 \mathrm{~d}$ and sun drying on a black plastic sheet took $6 \mathrm{~d}$. After drying, the duckweed was weighed and stored in $50 \mathrm{~kg}$ bags ready for use as chicken feed.

At Nemanwa the chicken project was run by the youth whilst at Gutu the chicken project was abandoned within a year's time. The chicks are fed on a conventional broiler starter mash for the first three weeks after which they are put on a diet with varying proportions of duckweed (0\%, $10 \%$ and $20 \%$ duckweed by mass). Tests done at the University of Zimbabwe showed that duckweed could be incorporated in broiler rations up to $10 \%$ level without compromising growth performance or carcass composition (Kusina et al., 1999). This confirmed previous findings elsewhere (Huque et al., 1997). Samples sent for broiler performance and microbiological analysis confirmed that the chickens from both centres were suitable for human consumption (IWSD, 2000). At Nemanwa, a small vegetable gardening project was started in 2000 using chicken droppings and dried excess duckweed as manure. Unfortunately, the gardening project has failed to make an impact because of perennial water rationing in the area.

\section{Effluent characteristics}

Typical raw sewage characteristics for selected towns in Zimbabwe are shown in Table 1 . There is a wider variation in concentration levels due mainly to the household water consumption patterns for domestic sewage. In some areas, raw sewage becomes highly concentrated in the hotter months of September to November and this can have effects on treatment performance. In terms of duckweed systems, there would be problems with ammonia poisoning, as duckweed requires about 20 to $60 \mathrm{mg} \mathrm{N} \cdot \ell^{-1}$ to grow actively. Above this range, a toxic effect has been reported due to high levels of free ammonia in the water (Das, 1998; Kyoburungi, 1998; Caicedo et al., 2000). At $\mathrm{pH}<7$ and temperatures around $25^{\circ} \mathrm{C}$, all the ammonia is dissolved as $\mathrm{NH}_{4}$. The $\mathrm{NH}_{3}$, a lipid soluble compound, easily passes biological membranes than the charged and hydrated ammonium ion (Koning et al., 1987). Bollaños (1999) reported that the effect of $\mathrm{NH}_{3}$ to duckweed is more pronounced than that of $\mathrm{NH}_{4}^{+}$, and $\mathrm{NH}_{3}$ appears to be the main
TABLE 1

Typical raw sewage characteristics for some selected Zimbabwean towns (Source: City of Harare database; IWSD, 2000; Nhapi et al., 2003)

\begin{tabular}{|l|c|c|c|c|}
\hline \multirow{2}{*}{ Parameter } & \multicolumn{4}{|c|}{ Sewage treatment plant and town } \\
\cline { 2 - 5 } & $\begin{array}{c}\text { Crowborough, } \\
\text { Harare }\end{array}$ & $\begin{array}{c}\text { Firle, } \\
\text { Harare }\end{array}$ & $\begin{array}{c}\text { Nemanwa, } \\
\text { Masvingo } \\
\text { Province }\end{array}$ & $\begin{array}{c}\text { Gutu, } \\
\text { Masvingo } \\
\text { Province }\end{array}$ \\
\hline $\mathrm{BOD}_{5}, \mathrm{mg} \cdot \ell^{-1}$ & 740 & 520 & 500 & 450 \\
$\mathrm{COD}, \mathrm{mg} \cdot \ell^{-1}$ & 1060 & 1100 & 1000 & 900 \\
$\mathrm{TKN}, \mathrm{mg} \cdot \ell^{-1}$ & 35 & 38 & 79 & 26 \\
$\mathrm{NH}-\mathrm{N}, \mathrm{mg} \cdot \ell^{-1}$ & 21 & 23 & 49 & 58 \\
Total N, mg $\ell^{-1}$ & 37 & 40 & 128 & 84 \\
Total P, mg $\cdot \ell^{-1}$ & 9 & 8 & 13 & 8 \\
$\mathrm{SS}, \mathrm{mg} \cdot \ell^{-1}$ & 888 & 586 & & 7.1 \\
$\mathrm{pH}$ & 6.6 & 6.8 & 7.2 & 7.1 \\
\hline
\end{tabular}

cause of toxicity to duckweed growth for concentrations above 0.4 $\mathrm{mg} \cdot \ell^{-1}$. The general influent quality in Zimbabwe requires that the raw sewage be pretreated to reduce its strength before entering the duckweed-covered lagoon.

\section{Area requirements and design considerations}

Duckweed grows on the surface of ponds so its yield can be optimised by providing optimal growth area. Literature figures suggest 20 to $90 \mathrm{~cm}$ for depth (Metcalf and Eddy, 1991; Iqbal, 1999), but this will also be governed by harvesting mechanisms. Providing narrow channels in a winding form would promote plugflow conditions and ensure easier access for harvesting. When a small boat is used for harvesting, a depth of about $1 \mathrm{~m}$ would suffice. Using a wastewater production rate of $80 \ell \cdot \mathrm{cap}^{-1} \cdot \mathrm{d}^{-1}$ (JICA, 1996) and a retention time of about $37 \mathrm{~d}$ would imply an area of about $4 \mathrm{~m}^{2} \cdot \mathrm{PE}^{-1}$ in Zimbabwe. This is twice the literature figures of $2 \mathrm{~m}^{2} \cdot \mathrm{PE}^{-1}$ for natural systems (Metcalf and Eddy, 1991). Ndamba and Murenga (1998) recommended a figure of 1 ha per 5000 people as a guide for Zimbabwe (the same as $2 \mathrm{~m}^{2} \cdot \mathrm{PE}^{-1}$ ).

In theory, Zimbabwean effluent nutrient standards of $10 \mathrm{mg} \cdot \ell^{-1}$ total TN and $1 \mathrm{mg} \cdot \ell^{-1} \mathrm{TP}$ (Zimbabwe Government S.I. 274 of 2000) are achievable. However, from a sustainable nutrient management point of view, the DPS effluent should be further usefully applied for other purposes like fish farming and crop irrigation (Gijzen and Kondker, 1997; FAO, 1999). Nhapi et al. (2003) recommended a DPS design which is flexible enough to change over to waste stabilisation pond systems when adverse conditions in influent quality are obtained. In some cases, this would require the inclusion of a parallel pair of anaerobic ponds as a form of pretreatment.

\section{Industrial applications}

Although natural systems are prone to poisoning by industrial effluents, duckweeds are known to tolerate and accumulate heavy metals with accumulation factors ranging $10^{2}$ to $10^{5}$ (Iqbal, 1999). Experiments have been carried out on chromium removal using duckweed and these had positive results (Sultan, 1999). Lemna gibba was used and it effectively removed chromium in the range of 30 to $40 \mathrm{mg} \cdot \mathrm{g}^{-1} \mathrm{dry}$ mass at concentrations below $30 \mathrm{mg} \cdot \ell^{-1}$. The main removal mechanism was via adsorption, with hardly any uptake. In Zimbabwe, duckweed has been used for removing $\mathrm{Cr}^{6+}$ 


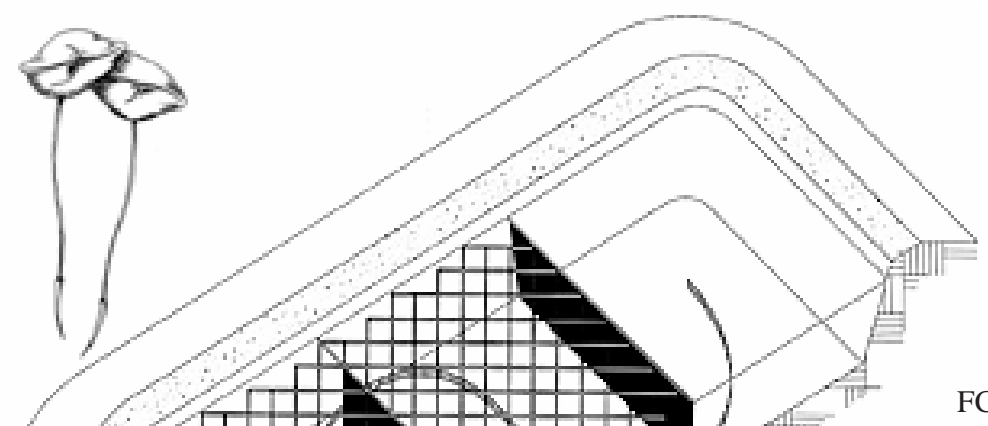
to $\left.3.2 \cdot \mathrm{d}^{-1}\right)$ compared to shallow algae ponds $\left(\mathrm{K}_{\mathrm{d}}=4.0\right.$ to $\left.5.9 \cdot \mathrm{d}^{-1}\right)$. He further showed that intermittent algae removal by inserting duckweed ponds in a series of shallow algae ponds increased the FC decay rates in the shallow algae ponds.

\section{Problems experienced}

The main problem encountered at Gutu and Nemanwa was the dieoff of duckweed during some periods, especially the hotter months of October to December. The nature of the influent pointed to ammonia toxicity due to high $\mathrm{pH}$ and temperature levels. The dieoffs occurred simultaneously with those at a newly established duckweed pond system in KweKwe, in the Midlands Province. Significantly, this did not happen at Zisco in the nearby town of Redcliff (15 km away) where duckweed is used to treat industrial effluent. No documentation is available on the system at Zisco to make informed inferences. The operation and maintenance requirements of DPS are new in Zimbabwe and hence more trials are required before appropriate guidelines can be set. As a result, problems are often encountered especially with harvesting routines resulting in poor performance in terms of nutrient and organic load reductions.

\section{Nutrient recovery potential}

Like any other wastewater treatment system, DPSs need constant monitoring. Because of longer response and retention times, monitoring of parameters like $\mathrm{TKN}, \mathrm{NH}_{4}^{+}, \mathrm{NO}_{3}, \mathrm{O}-\mathrm{PO}_{4} \mathrm{COD}$, temperature, $\mathrm{pH}$ and $\mathrm{DO}$ should be done monthly. The stocking density and harvesting rate should also be monitored to achieve optimal nutrient growth and recovery. A configuration like that shown in Fig. 1 is necessary to prevent wind effects. Floating booms dividing the pond into about $50 \mathrm{~m}^{2}$ bays could also be used. Weeding of pond edges is also necessary to avoid mosquito breeding.

\section{Duckweed species found in Zimbabwe}

Duckweeds belong to four genera; Lemna, Spirodela, Wolfia and Wolfiella. They have a wider occurrence with locally found species recommended for local trails. In Zimbabwe Sipirodella punctata, Wolffia arrhiza, Lemma perpusila and Lemma minor have been identified (IWSD, 1996). In 2002, Persicaria shegalanse was also identified at Nemanwa. However, there could be more species but there were problems in getting readily available expertise to positively identify the species when the speciation study was carried out. It has been noticed that in most cases at least two species co-exist. Some experiments have been done with Lemma minor and most of its characteristics are well documented (Skillicorn et al., 1993; Kusina et al., 1999).

\section{Pollution removal efficiencies}

Nhapi et al. (2003) reported nitrogen removal efficiencies of $87 \%$
The amount of nutrients that can be effectively recovered and reused via duckweed harvesting should not be exaggerated. Fresh duckweed generally contains 92 to 94\% water (Huque et al., 1997; FAO, 1999). In Zimbabwe, Kusina et al. (1999) found composition values of $89.2 \%$ water, crude protein $29.6 \%$ of dry matter (DM), and phosphorus $0.34 \%$ of DM for wastewater-grown duckweed. Gijzen (1997) reported the following values for wastewater-grown duckweed; DM 7.86\%, N 4.80\% of DM, and P 1.10\% of DM. Duckweed from natural colonies contains about 14 to $25 \%$ protein but under ideal conditions, when harvested regularly, the protein content may increase to 35 to $45 \%$ (Huque et al., 1997). In this study, potential nutrient recovery by DPS in Zimbabwe was modelled using local unit figures of $80 \ell \cdot \mathrm{cap}^{-1} \cdot \mathrm{d}^{-1}$ wastewater production (high density residential areas), $8 \mathrm{~g} \cdot \mathrm{cap}^{-1} \cdot \mathrm{d}^{-1} \mathrm{TN}$ and 1.1 g. cap $^{-1} \cdot \mathrm{d}^{-1}$ TP production (JICA, 1996; City of Harare Sewerage Masterplan Document, 2001). A pond depth of $0.75 \mathrm{~m}$ to allow for harvesting by boat, and $37 \mathrm{~d}$ hydraulic retention time was used (Figs. 2 and 3). This showed that 16\% TN and 26\% TP can be recovered in the harvested duckweed. When wastewater consumption is high at $100 \ell^{\cdot} \cdot \mathrm{cap}^{-1} \cdot \mathrm{d}^{-1}$, these figures rise to $20 \% \mathrm{TN}$ and $33 \%$ $\mathrm{TP}$ respectively. This has far-reaching consequences in terms of where DPS should be used. Since less concentrated waters are related to medium and low-density residential areas (JICA, 1996), it would make sense to use them for such areas, consequently avoiding problems related to high nitrogen concentrations. Care also needs to be taken to avoid industrial toxins into DPS by treating industrial wastes separately. 


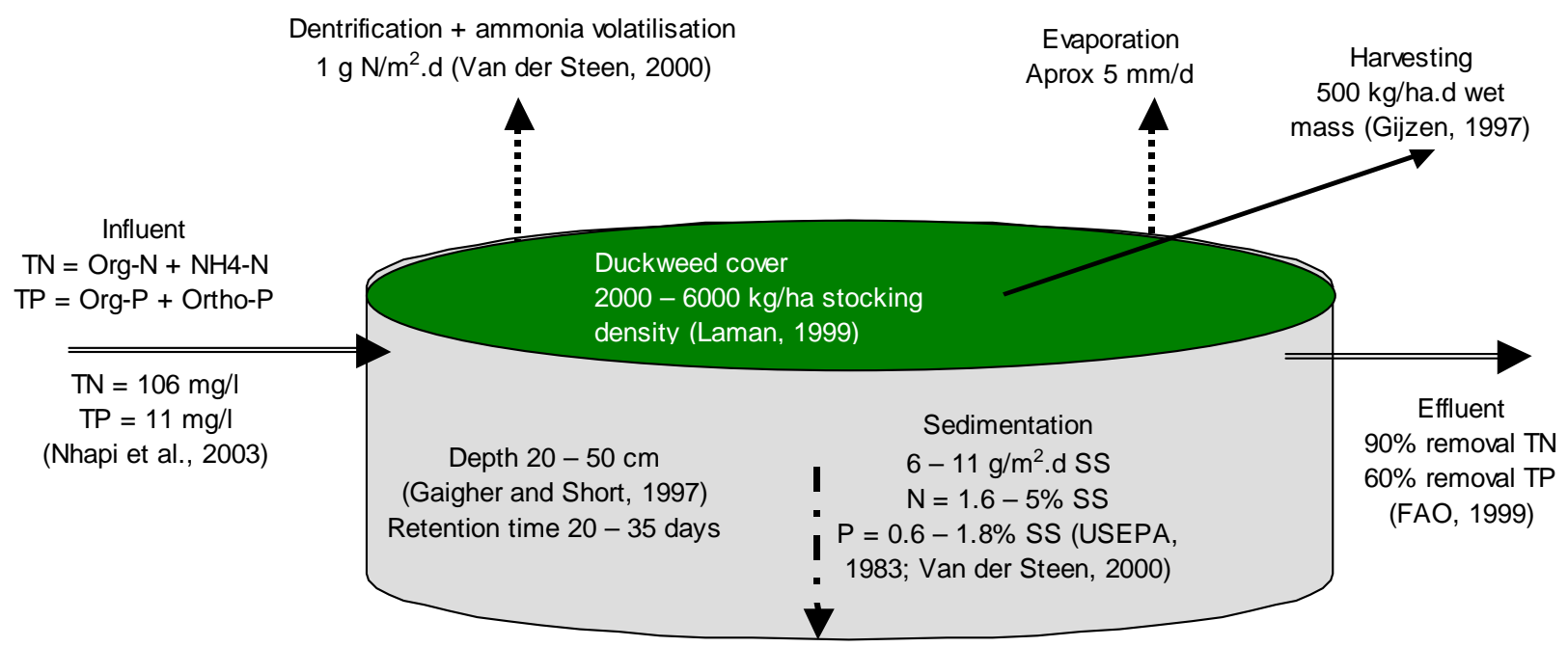

Figure 2

Fate of nutrients at a DPS plant (based on literature figures as shown on the diagram)

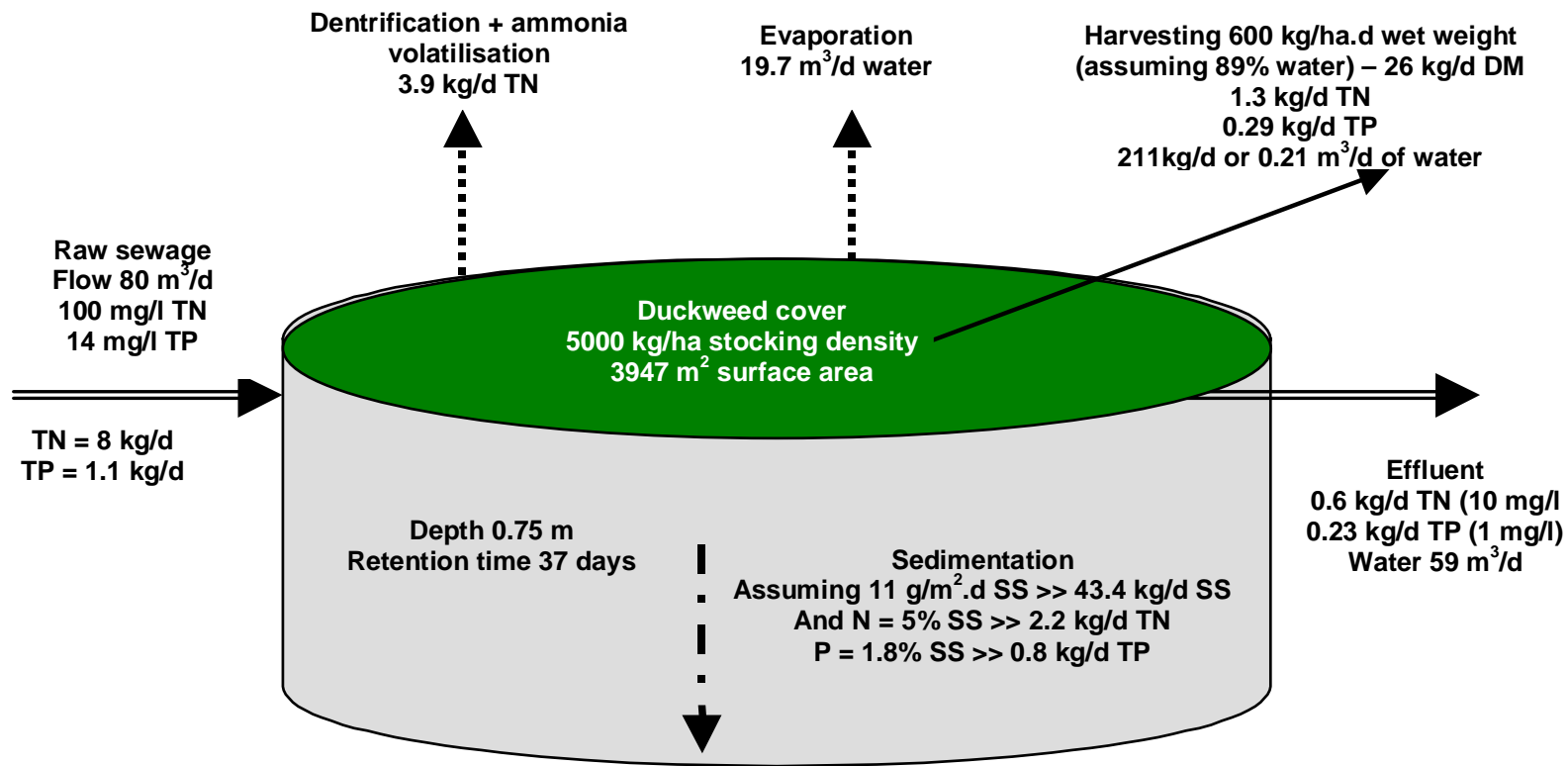

Figure 3

Theoretical duckweed nutrient and water balance in typical Zimbabwean conditions under dry weather conditions (based on Fig. 2)

Figure 2 suggests that under optimal conditions, the harvested duckweed would require a large poultry project or other alternatives. Aquaculture and composting of duckweed for use in agriculture are some of the alternatives. A broiler consumes about $4 \mathrm{~kg}$ of food in a period of 8 weeks. Five of these weeks will be on a conventional broiler finisher mash. Incorporating $10 \%$ of total feed as duckweed implies that $0.25 \mathrm{~kg}$ would be dried duckweed. A simple spreadsheet mass balance model of water and nutrients in a typical duckweed-based pond system was developed using Fig. 2 and the results of this model are presented in Fig 3. From this model, one person potentially produces about $9.5 \mathrm{~kg} \cdot \mathrm{yr}^{-1} \mathrm{DM}$ duckweed, enough to feed 38 chickens as supplementary feed. Considering that chickens are sold for about Z\$6 000 (USD6) per bird, a study on the economic benefits of a poultry project will be very interesting.

Figure 3 only shows what would be expected if it is assumed that all duckweeds behave almost the same under different conditions. This is not true in the real world although certain lessons can be learnt from this model. The first one has already been touched on and it is that DPS would favour areas of moderate wastewater production. This would increase nutrient recovery through harvesting up to a point when nutrient availability becomes a limiting factor. According to literature this is a point when $\mathrm{TN}<20 \mathrm{mg} \cdot \ell^{-1}$ (Caicedo et al., 2000). The second one is that TP losses via sedimentation account for about $70 \%$ of TP-removal. Unless the sludge is removed regularly and used as manure for crop production, this might be a waste of valuable resources. However, because of current tight legislation, effluent discharge criteria are an over- 
riding factor and means for promoting settlement (higher retention time, shallow depths, quiescent conditions) have to be provided. The third aspect is that evapotranspiration could account for more that $20 \%$ water losses making effluent criteria based on concentration meaningless and misleading in such systems. The model also showed that effluent standards of $10 \mathrm{mg} \cdot \ell^{-1} \mathrm{TN}$ and $1 \mathrm{mg} \cdot \ell^{-1} \mathrm{TP}$ in Zimbabwe could be met using DPS. The challenge, therefore, is to ensure that treatment plants actually achieve the model operating conditions, taking into account that some figures used were not locally derived.

Certain decisions have to be made when designing duckweed systems. The first one is on pretreatment. Normal settling methods would reduce organic and nutrient loadings to subsequent duckweed-covered units. However, anaerobic pretreatment is favourable as it substantially reduces the organic load whilst releasing readily available nutrients for duckweed uptake. The other decision is on pathogen reduction. Depending on the proposed effluent reuse envisaged, and therefore the degree of exposure to risk, further effluent polishing using shallow maturation ponds is recommended. The $37 \mathrm{~d}$ hydraulic retention time (HRT) recommended from the model in Fig. 3 should be almost sufficient to ensure substantial pathogen reduction, so the HRT in the maturation pond could be reduced. The actual figure needs to be determined from further research.

\section{Conclusions and recommendations}

Duckweed-based pond systems are an ideal wastewater treatment technology for Zimbabwe because they potentially meet the local effluent disposal guidelines whilst also providing further opportunities for nutrient recovery and reuse. Such systems have been tried in Masvingo Province since June 1999 where a few problems where experienced because of design defects and nutrient concentrations at some times of the year. A model mass balance of water and nutrients revealed that DPSs are quite efficient in nutrient removal but should be used in areas of moderately concentrated wastewater. It is therefore recommended that DPSs be used for small communities, where there are no industrial wastewaters. To improve their performance and the safety of users, pretreatment and effluent polishing means have to be decided on. It is recommended that further studies be conducted to improve the mass balance model developed in this study and to optimise operations of DPS.

\section{Acknowledgements}

This research was generously supported by a SIDA/SAREC Research grant and the Netherlands Government through the WREM Programme at the University of Zimbabwe. Co-operation by the Institute of Water and Sanitation Development, Masvingo Rural District Council, and the Central Rates Fund at Mupandawana, is gratefully acknowledged.

\section{References}

BOLLAÑOS FC (1999) The Effects of Ammonium, Ammonia and pH on the Growth of Duckweeds in Continuous Flow Wastewater Systems. IHE Delft M.Sc. Thesis, Delft, The Netherlands

CAICEDO JR, VAN DER STEEN NP, ARCE O and GIJZEN, HJ (2000) Effect of total ammonia nitrogen concentration and $\mathrm{pH}$ on growth rates of duckweed (Spirodela polyrrhiza), IWA Water Sci. Technol. 15 3829-3835.

DAS SK (1998) Ammonia Toxicity of Lemna Gibba Adapted and Grown in Settled Domestic Wastewater. IHE Delft M.Sc. Thesis, Delft, The Netherlands.
DLG (DEPARTMENT OF LOCAL GOVERNMENT) (1998) Environment and Health Protection Guidelines: Onsite Sewage Management for Single Households. State Government of New South Wales, Bankstown, Australia.

FAO (1999) Duckweed - A Tiny Aquatic Plant with Enormous Potential for Agriculture and Environment. FAO Publications, Rome, Italy.

GIJZEN HJ (1998) Sustainable wastewater management via reuse: Turning waste into wealth. In: Proc. Aqua 98, Water and Sustainability. 1-4 June 1998, Cali, Colombia.

GIJZEN HJ (1997) Scientific and Technical Validation of PRISM Duckweed Activities. PRISM Duckweed Project Report, Dhaka, Bangladesh.

GIJZEN HJ and KONDKER M (1997) An Overview of the Ecology, Physiology, Cultivation and Application of Duckweed. Inception Report. ANNEX 1. Literature Review. Duckweed Research Project (DWRP). Dhaka, Bangladesh.53 pp.

HUQUE EQM, PAUL DG, UDDIN SM and IKRAMULLAH M (1997) Effects of duckweed on the performance of broilers. In: Gijzen $\mathrm{H}$ (1997) Preliminary Research Results. PRISM Duckweed Project Reports, Dhaka, Bangladesh.

IQBAL S (1999) Duckweed Aquaculture; Potentials, Possibilities and Limitations for Combined Wastewater Treatment and Animal Feed in Developing Countries. SANDEC Report No. 6/99, EAWAG/SANDEC, Duebendorf, Switzerland.

IWSD (1996) Assessment of Wastewater Treatment Using Duckweed. Annual Report January - December 1996, IWSD, Harare, Zimbabwe.

IWSD (1999, 2000) An Investigation into the Potential Use of Duckweedbased Waste Stabilisation Ponds for Wastewater Treatment in Small Urban Areas of Zimbabwe. Annual Progress Report, IWSD, Harare, Zimbabwe.

JICA REPORT (1996) The Study of Water Pollution Control in Upper Manyame River Basin in the Republic of Zimbabwe. MLGRUD, Nippon Jogeduido Sekkei Co. Ltd., Nippon Koei Co. Ltd.

KING N (2000) New Strategies for Environmental Sanitation. In: Water21, Magazine of the International Water Association. April 2000, London, UK. 11-12.

KONING A, PEARSON HP and SILVA SA (1987) Ammonia toxicity to algal growth in waste stabilisation ponds. Water. Sci. Technol. 19 115-122.

KYOBURUNGI G (1998) The Effect of Shock-Loading on Wastewater Treatment Efficiency of Duckweed-Covered Systems. IHE Delft M.Sc. Thesis, Delft, The Netherlands.

KUSINA J, MUTISI C, GOVERE W, MHONA R, MURENGA K, NDAMBA J and TAYLOR P (1999) Evaluation of duckweed (Lemna minor) as a feed ingredient in the finisher diets of broiler chickens. JASSA 5 (1) 25-33.

LAMAN C (1999) Influence of Duckweed Stocking Densities on the Growth Rates of Lemna Gibba. IHE Delft Traineeship Report, Delft, The Netherlands.

LENS P, ZEEMAN G and LETTINGA G (eds.) (2001) Decentralised Sanitation and Reuse: Concepts, Systems, and Implementation. IWA Publishing, London, UK.

METCALF and EDDY (1991) Wastewater Engineering: Treatment, Disposal and Reuse. Mcgraw-Hill, Inc, Singapore.

NDAMBA J and MURENGA K (1998) Duckweed Based Wastewater Stabilisation Ponds: A Guide for Use in Zimbabwe. Institute of Water and Sanitation Development, Harare, Zimbabwe.

NHAPI I, DALU J, NDAMBA J and GIJZEN HJ (2001) Sustainable decentralised sanitation using duckweed-based ponds. Proc. 27 $7^{\text {th }}$ WEDC Conf., Lusaka, Zambia, 228-231.

NHAPI I, HOKO Z, SIEBEL M and GIJZEN HJ (2002) Assessment of major water and nutrient flows in the Chivero catchment area, Zimbabwe. Phys. and Chem. of the Earth 27 783-792.

NHAPI I, DALU J, NDAMBA J and GIJZEN HJ (2003) An evaluation of duckweed-based pond systems as an alternative option for decentralised treatment and reuse of wastewater in Zimbabwe. Water. Sci. Technol. 48 (11) 115-122.

ORON G, WILDSCHUT LR and PARATH D (1984) Wastewater recycling by duckweed for protein production and effluent renovation. Water. Sci. Technol. 17 803-817.

RMI (Rocky Mountain Institute) (2000) Valuing Decentralised Technologies for Water Quality Protection: A Catalogue of Benefits and 
Economic Analysis Techniques. Rocky Mountain Institute, Colorado, USA, Internet Site: http:www.rmi.org.

SKILLICORN P, SPIRA W and JOURNEY W (1993) Duckweed Aquaculture: A New Aquatic Farming System for Developing Countries. World Bank, Washington, USA

SULTAN AMH(1999) Removal of Chromium from Industrial Wastewater by Lemna gibba. IHE Delft M.Sc. Thesis, Delft, The Netherlands.

USEPA (1997) Response to Congress on the Use of Decentralised Waste
Water Treatment Systems. U.S. Environmental Protection Agency Washington, D.C. EPA 832-R-97-001b.

VAN DER STEEN P (2000) Faecal Coliform Removal from UASB Effluent in Integrated Systems of Algae and Duckweed Ponds. Ph.D. Thesis, Ben-Gurion Univ. of the Neger, The Netherlands.

VENHUIZEN D (1997) The Decentralised Concept of Wastewater Management. Internet Site: http://www.geocities.com/RainForest/Vines/ 5240/Venh_ww.html. 